\title{
THE EFFECT OF TUNGSTEN CARBIDE PARTICLES CONTENT IN A WELD DEPOSIT ON ITS ABRASION RESISTANCE
}

\author{
Ivo Hlavatý, Jindřich Kozák, Lucie Krejčí, Ivan Samardžić, Jari Tuominen
}

Original scientific paper

This paper describes the study of a weld deposit which contains tungsten carbide particles. For testing the process of gas metal arc welding in a protective atmosphere of a mixed gas with two types of cored wires were used. The selected cored electrode of a "F-Durit G" type already contains the tungsten carbide particles. The second used option was a cored electrode of a "Megafil A 864M" type with an increased boron content. For the second variant tungsten carbide particles with a 1-2 mm size were added to the weld pool, and a composite material layer was thus created. For the mentioned test two different levels of welding parameters were selected and the final weld deposit properties, particularly their abrasion resistance, were examined.

Keywords: abrasion; carbide; electric arc; tungsten; vibratory feeder; welding matrix

Učinak sadržaja čestica karbida volframa u naslagi zavara na njegovu otpornost na abraziju

Izvorni znanstveni članak

U radu se daje analiza naslage zavara koja sadrži čestice karbida volframa. U ispitivanju je primijenjen postupak elektrolučnog zavarivanja u zaštićenoj atmosferi miješanog plina s dva tipa žice s jezgrom. Izabrana elektroda s jezgrom tipa "F-Durit G" već sadrži čestice karbida volframa. Druga primijenjena opcija bila je elektroda s jezgrom tipa "Megafil A $864 \mathrm{M}$ " s povećanim sadržajem borona. U drugoj su varijanti čestice karbida volframa veličine 1-2 mm dodane u zavar i tako je stvoren sloj od kompozitnog materijala. Za spomenuti pokus izabrana su dva različita nivoa parametara zavarivanja, a mi smo ispitivali svojstva završne naslage zavara, a naročito otpor na abraziju.

Ključne riječi: abrazija; električni luk; karbid; matrica; vibracijski napajač; volfram; zavarivanje

\section{Introduction}

Today, practically every industry uses different technologies and a combination of materials which increase the resistance against the many types of wear such as abrasion, adhesion, corrosion and that sort of thing. These technologies could include thermal spraying (plasma, flame, etc.) [1-3], vacuum evaporation (V-EPC) and various hard-facing methods $[5,6]$ which include flame, laser, plasma or arc welding in the inert protective atmosphere used in this article. Different results can be achieved by a different variation of the cored electrodes. The final properties of a weld deposit may be influenced by the welding parameters as well. Thanks to all these methods protective layers using composite materials can be created consisting of a tough matrix with hard particles. The most widely used matrix is based on nickel, iron, or cobalt material. As hard particles various kinds of carbides, nitrides or borides reinforcing the matrix can be used. A combination of hard and tough material consequently achieves unique properties, which are gained from the advantages of both materials. These materials are characterized by increased wear resistance. This paper deals with the influence of tungsten carbide (chemical formula: WC) in a combination with an ironbased martensitic matrix and the final abrasive properties of the protective layer on the surface of structural steel; it is a heterogeneous joint [7]. Further, similarly to [9, 10], the influence of the welding parameters and particles distribution was examined [11, 12]. A Lincoln Electric vibratory feeder was used for the transportation of WC particles to the surface layers for the TC02 and TC06 samples.

Several authors of the research works [14-16] have been concentrated on the inspection methods and properties of weld joints in welding process.

\section{Experimental part}

\subsection{Material and welding technology}

Non-alloyed carbon steel S235JR was chosen for the experiment, the chemical composition is given in Tab. 1 . In this paper we examined two types of weld deposits in two different variants. In total we tested four samples.

Table 1 Composition of base material

\begin{tabular}{|c|c|c|c|c|c|c|c|}
\hline \multicolumn{7}{|c|}{ Chemical Composition Table / wt. \% } \\
\hline $\mathrm{C}$ & $\mathrm{Mn}$ & $\mathrm{Si}$ & $\mathrm{S}$ & $\mathrm{P}$ & $\mathrm{Cr}$ & $\mathrm{Ni}$ & $\mathrm{Cu}$ \\
\hline 0.14 & 0.67 & 0.20 & 0.019 & 0.01 & 0.02 & 0.01 & 0.01 \\
\hline $\mathrm{Ti}$ & $\mathrm{Al}$ & $\mathrm{As}$ & $\mathrm{N}$ & $\mathrm{Mo}$ & $\mathrm{V}$ & $\mathrm{Nb}$ & $\mathrm{Fe}$ \\
\hline 0.003 & 0.046 & 0.002 & 0.006 & 0.001 & 0.003 & 0.002 & rest \\
\hline
\end{tabular}

We selected two types of filler material which forms the matrix for the tungsten carbide particles. "Zander Schweisstechnik F-Durit G" cored wire was selected for the TC01 and TC05 samples with a diameter of $1.6 \mathrm{~mm}$ (see Tab. 2). The mentioned cored wire is filled with tungsten carbide (FTC) that is designed for weld deposits which are exposed to the different types of wear such as sand or for the mineral processing industry. The weld deposits should be formed by a martensitic matrix with embedded particles of tungsten carbide. The shielding gas was selected according to the manufacturer's requirements - a mixture comprising $82 \%$ argon and $18 \%$ carbon dioxide.

Table 2 Chemical composition / filler material for TC01 and TC05 samples

\begin{tabular}{|c|c|}
\hline \multicolumn{2}{|c|}{ Chemical Composition Table / wt. \% } \\
\hline WC & matrix C, Fe \\
\hline 57 & 43 \\
\hline
\end{tabular}

The filler material "Megafil A 864M" (see Tab. 3) was used for the TC02 and TC06 samples. A cored wire 
with the $1.6 \mathrm{~mm}$ diameter is specially designed for components in the mining, steelmaking and agricultural sectors. The wire is alloyed with an increased volume of boron and the weld deposit should consist predominantly of the martensitic matrix. In this case, an argon and nitrogen mixture in a ratio of $50 \% / 50 \%$ was used as shielding gas.

Table 3 Chemical composition / filler material for TC02 and TC06 samples

\begin{tabular}{|c|c|c|c|c|c|c|c|c|}
\hline \multicolumn{1}{|c|}{ Chemical composition table / wt. \% } \\
\hline $\mathrm{C}$ & $\mathrm{Si}$ & $\mathrm{Mn}$ & $\mathrm{P}$ & $\mathrm{S}$ & $\mathrm{Cr}$ & $\mathrm{Ni}$ & $\mathrm{B}$ & Fe \\
\hline 0.426 & 0.27 & 1.05 & 0.025 & 0.025 & 0.27 & 1.57 & 4.62 & rest \\
\hline
\end{tabular}

As a hard-facing technology, gas metal arc welding with a cored wire and shielding mixed gas was selected. The additional material of the TC01 and TC05 samples contains tungsten particles in their filling structure. For TC02 and TC06 an addition of tungsten carbide particles was put into the molten pool just behind the electric arc by the vibratory feeder. Two different levels of welding parameters were selected for each of the weld deposits (see Tab. 4). Each weld deposit was created from one layer which consists of six welding beads.

Table 4 Welding parameters

\begin{tabular}{|c|c|c|c|c|}
\hline & TC01 & TC02 & TC05 & TC06 \\
\hline $\begin{array}{l}\text { Electric } \\
\text { Current }\end{array}$ & $225 \mathrm{~A}$ & $250 \mathrm{~A}$ & $170 \mathrm{~A}$ & $210 \mathrm{~A}$ \\
\hline $\begin{array}{l}\text { Electric } \\
\text { Voltage }\end{array}$ & $30 \mathrm{~V}$ & $27 \mathrm{~V}$ & $23.4 \mathrm{~V}$ & $28.3 \mathrm{~V}$ \\
\hline $\begin{array}{l}\text { Welding } \\
\text { Speed }\end{array}$ & $6-7 \mathrm{~mm} / \mathrm{s}$ & $4-5 \mathrm{~mm} / \mathrm{s}$ & $2-3 \mathrm{~mm} / \mathrm{s}$ & $6-7 \mathrm{~mm} / \mathrm{s}$ \\
\hline Gas Flow & $18 \mathrm{l} / \mathrm{min}$ & $18 \mathrm{l} / \mathrm{min}$ & $18 \mathrm{l} / \mathrm{min}$ & $18 \mathrm{l} / \mathrm{min}$ \\
\hline $\begin{array}{c}\text { WC } \\
\text { Particle } \\
\text { (Size) }\end{array}$ & $\begin{array}{l}\text { yes } \\
(\approx 0.1 \\
\mathrm{mm})\end{array}$ & $\begin{array}{c}\text { yes } \\
(\approx 1-2 \mathrm{~mm})\end{array}$ & $\begin{array}{c}\text { yes } \\
(\approx 0.1 \mathrm{~mm})\end{array}$ & $\begin{array}{c}\text { yes } \\
(\approx 1-2 \mathrm{~mm})\end{array}$ \\
\hline Quantity & - & $\begin{array}{c}40 \mathrm{~g} / 100 \\
\mathrm{~mm}\end{array}$ & - & $\begin{array}{c}40 \mathrm{~g} / 100 \\
\mathrm{~mm}\end{array}$ \\
\hline $\begin{array}{c}\text { Filler } \\
\text { Material }\end{array}$ & F-Durig G & A864 M & F-Durig G & A864 M \\
\hline
\end{tabular}

\section{Micro-hardness HV0.1}

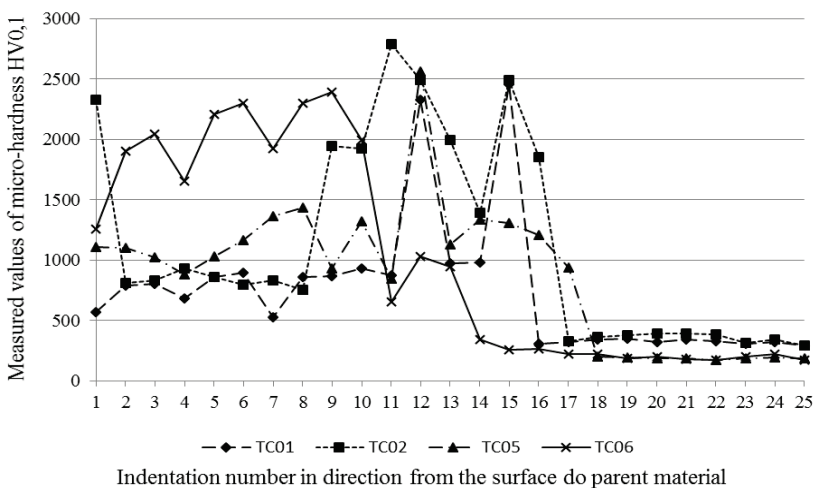

Figure 1 Micro-hardness values HV0.1: Microhardness of primary WC particles reached value around 2000 HV0.1 or more

\subsection{Micro-hardness measurement}

The tested samples were created from weld deposits, the perpendicular cuts to the welding direction. 25 punctures for the Vickers hardness test HV0.1 $(0.98 \mathrm{~N}$ loads) were done. The mentioned hardness measurement was performed in a direction from the surface to the base material. The main purpose of the measurement was to determine the hardness of a weld deposit, the melting boundary, and heat affected zone in the base material (see Fig. 1). Matsuzawa MMT-X7 was used as a measuring device.

\subsection{Test method for abrasion resistance}

The test of abrasion resistance corresponds to the ASTM G65 standard (see Fig. 2). The samples were in the form of blocks. The weld deposit area has a dimension of $50 \times 20 \mathrm{~mm}$ and is subsequently exposed to abrasives (silica sand with sizes starts from $0.1 \mathrm{~mm}$ to $0.6 \mathrm{~mm}$, the amount from 27 to $32 \mathrm{~g} / \mathrm{min}$ ), and is pressed to the rubber wheel by a pressure force of $23 \mathrm{~N}$ (using a $5 \mathrm{~kg}$ load and leverage) at speed $-60 \mathrm{rpm}$. The test was divided into 5 parts, the weight loss was measured each 12 minutes.

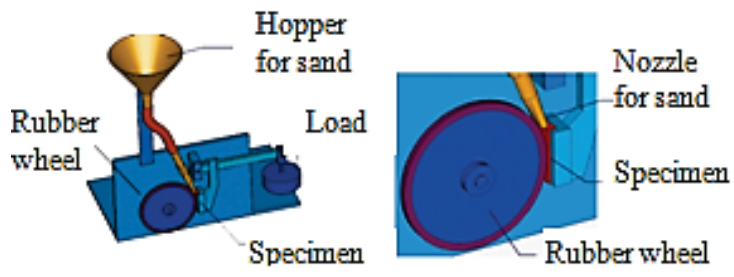

Figure 2 Scheme of abrasion resistance test [13]

\section{Results and discussion}

3.1 The microstructure of the surface weld and microHardness HV0.1

The martensitic structure of the TC01 sample shows a high level of secondary dendritic carbides (see Fig. 3) which are generated from molten primary tungsten carbides, which reach hardness up to of 981 HV0.1 (see Fig. 1). The fusion of the primary tungsten carbide particles was caused by an excessive heat input, charged to the molten bath. These dendrites are evenly distributed over the full cross section of the weld deposit. The structure also includes the isolated primary particles of tungsten carbide with a hardness up to $2455 \mathrm{HV} 0.1$. The percentage share of primary tungsten carbide to a matrix is approximately $0.5 \% / 99.5 \%$.

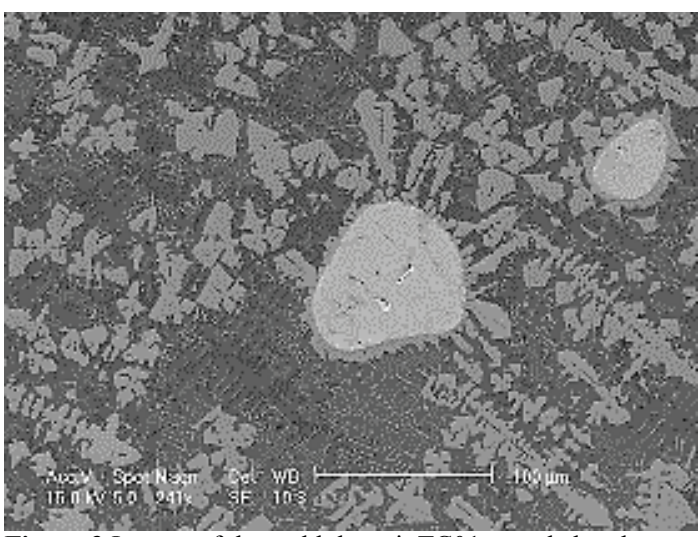

Figure 3 Images of the weld deposit TC01 sample by electron microscopy with primary WC particles

In some cases, the hardness of the matrix reached values up to $792 \mathrm{HV} 0.1$, which basically correspond to values for the manufacturer's wires (approx. $800 \mathrm{HV}$ ). 
The Heat Affected Zone (HAZ) had the micro-hardness of 348 HV0.1. The thickness of the weld deposit has a value from 3 to $5 \mathrm{~mm}$. The weld deposit TC02 (see Fig. 4) is mainly formed by a martensitic matrix with residual austenite [8]. The hardness of the matrix reached values up to $932 \mathrm{HV} 0.1$. The tungsten carbide size of $1-2 \mathrm{~mm}$ is embedded in the matrix, with hardness up to $2789 \mathrm{HV} 0.1$. The tungsten carbide ratio is approximately $40 \% / 60 \%$. These particles are located in the bottom of the weld deposit, which is caused by the higher weight of the particles in comparison with matrix. The weld deposit has cracks which were created by a different cooling rate between the matrix and tungsten carbide particles. These cracks do not have a significant negative impact on the weld deposit. The TC05 sample has a slightly higher proportion of primary tungsten carbide than the TC01 sample (see Fig. 5), the ratio is approximately $2 \%$ of tungsten carbide and $98 \%$ of matrix, and achieved the hardness value up to $2560 \mathrm{HV} 0.1$. This was achieved by reducing of the welding current against the TC01 sample. Secondary dendritic particles precipitated again with a finer microstructure compared with the TC01. The martensitic matrix with an amount of residual austenite reached a hardness value up to $844 \mathrm{HV} 0.1$. The heat affected zone reached 202 HV0.1. The thickness of the weld deposit has a value from 5 to $6 \mathrm{~mm}$.

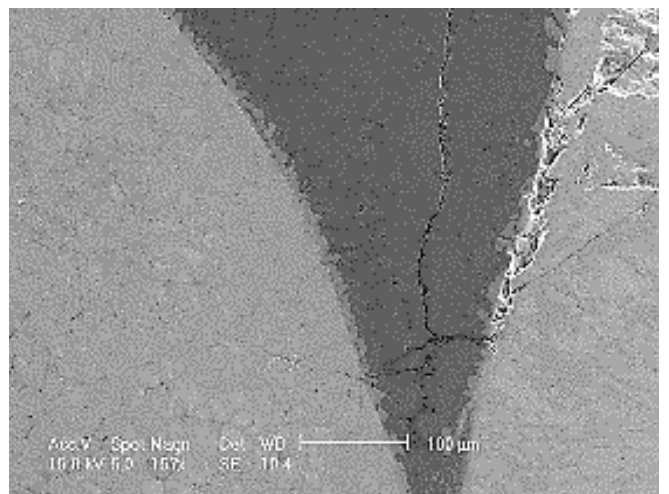

Figure 4 Images of weld deposit TC02 sample by electron microscopy with WC particles

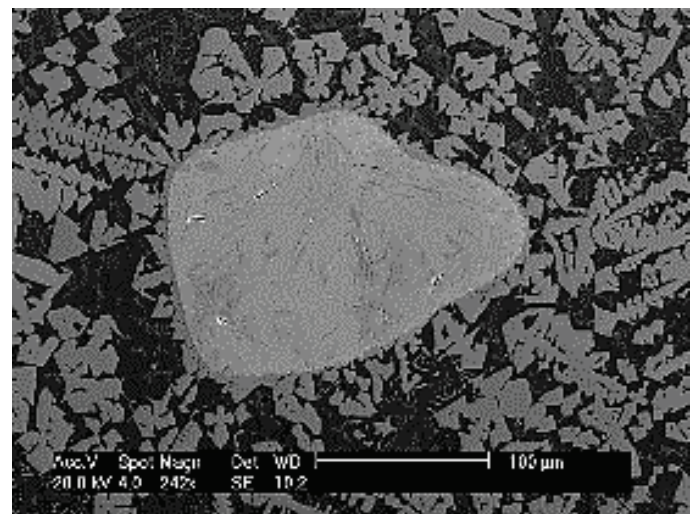

Figure 5 Images of weld deposit TC05 sample by electron microscopy with primary WC particles

The TC06 sample (see Fig. 6) was hard-faced with lower welding current than TC02 sample, which implies using of a smaller amount of additional material and reduced coherence of tungsten carbide with weld deposit matrix. Microstructure is martensitic. The lower heat input leads to reduction of penetration of the weld deposit into the base material and this could cause the weld cracking. During the examination of the cross section of weld deposit it was found that the tungsten carbide particles are equally spread in approximately the ratio of $38.4 \% / 61.6 \%$. The hardness of tungsten carbide particles reached values up to $2390 \mathrm{HV0.1}$ and hardness of matrix reached up to 948 HV0.1. The Heat Affected Zone (HAZ) had the hardness of 346 HV0.1. The thickness of weld deposit has a value from 4 to $5 \mathrm{~mm}$. There are cracks again in the weld deposit, and their incidence rate is so high that it reduces the consequent compactness of weld deposit and creates a peel off effect.

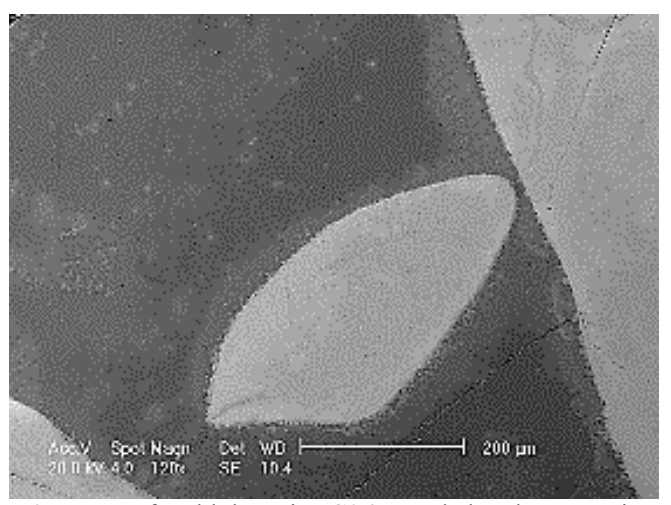

Figure 6 Images of weld deposit TC06 sample by electron microscopy with HWC particles

\subsection{Abrasion resistance testing}

Fig. 7 shows that the TC05 sample reached the lowest weight loss $(109 \mathrm{mg})$ although a large number of primary tungsten carbide particles were melted similarly to TC01. This may be caused by a lower level of degradation of tungsten carbide particles, which provided the necessary reinforcement of weld deposit, combined with effect of secondary tungsten carbide particles evenly distributed at weld deposits and matrix. TC01 reached the third lowest weight loss $(287 \mathrm{mg})$.

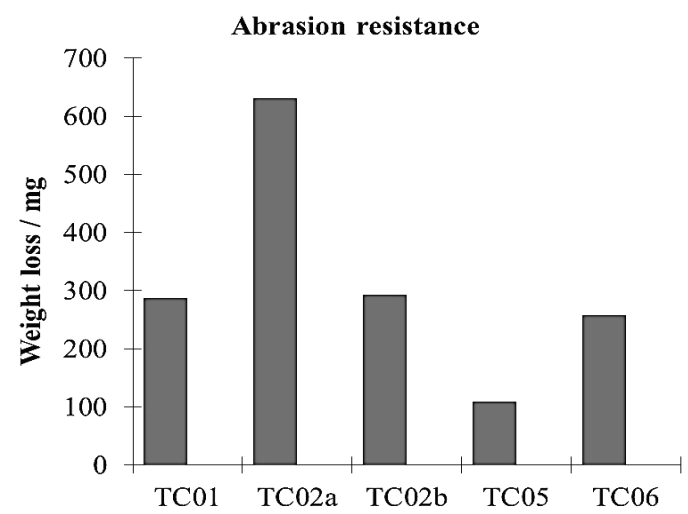

Figure 7 Comparison of weight loss; the TC02a sample shows a weight loss before modification of the weld deposit; TC02b after modification

The TC06 sample reached the second best result ( 258 $\mathrm{mg}$ ) with the particles proportion of tungsten carbides to matrix; the ratio of $38.4 \% / 61.6 \%$. The sample showed less than half weight loss in the test against the TC02a sample. This is achieved by optimal arrangement of tungsten carbide particles in weld deposit. They provide sufficient support to tough matrix. With respect to the information that the tungsten carbide particle occupies 
only a $7-8 \%$ of the surface area, it was necessary to modify the weld deposit of $\mathrm{TC} 02$ sample. The modification consisted of removing $1.5 \mathrm{~mm}$ layer of weld deposit, which contained a low percentage of tungsten carbide particles. This modification uncovered WC particles and helped to increase the proportion of tungsten carbide particles on the surface of weld deposit; approximately $24-25 \%$ of the area, sample TC02b. After a new test the loss weight moved from original $631 \mathrm{mg}$ to final $293 \mathrm{mg}$. The experiment proved a direct influence of tungsten carbide arrangement on the final weld deposit resistance to abrasive wear.

The surfaces of all samples showed the occurrence of shallow and deep scratches caused by abrasives. These scratches are the result of ploughing (the plastic deformation of the surface by abrasives) and cutting (an abrasive material with sharp edges acts as a cutting tool).

\section{Conclusions}

On the basis of the results, we concluded that the weld deposit properties reached very different values. The heat input and welding technology used have a major impact on weld deposit properties, which could be a very important factor in reaching satisfactory weld deposits.

The results of this study can be characterized as follows:

- The technology and welding parameters used caused that a preponderant value of tungsten carbide was melted in the TC01 and TC05 samples. The TC01 and TC05 microstructures showed the occurrence of secondary dendritic carbides, which replaced the function of the primary tungsten carbide particles.

- The TC05 sample proved the lowest weight loss after the abrasion resistance test even if the majority of primary tungsten carbide was melted.

- The TC06 sample with a combination of the martensitic matrix and the tungsten carbide (1-2 mm) particles showed the second lowest weight loss after the abrasion resistance test. This was achieved by an optimal arrangement of WC particles on the weld deposit.

- We verified that the combination of composite weld deposits, which are created by a tough matrix and hard particles, the proportion and their position on the surface, have a direct influence on the resistance of the weld deposits.

- The abrasion resistance test verified the effect of the surface abrasion type of wear. The surfaces of all samples showed occurrence of shallow and deep scratches caused by abrasives. These scratches were caused by a ploughing and cutting mechanism.

\section{References}

[1] Melendez, N. M.; McDonald, A. G.; Development of WCbased metal matrix composite coatings using low-pressure cold gas dynamic spraying. // Surface \& Coatings Technology. 214, (2013), pp. 101-109. https://doi.org/10.1016/j.surfcoat.2012.11.010

[2] Krishna, B. V.; Misra, V. N.; Mukherjee, P. S.; Puneet Sharma. Microstructure and properties of flame sprayed tungsten carbide coatings. // International Journal of
Refractory Metals \& Hard Materials. 20, (2002), pp. 355374. https://doi.org/10.1016/S0263-4368(02)00073-2

[3] Voyer, J.; Marple, B. R. Sliding wear behavior of high velocity oxy-fuel and high power plasma spray-processed tungsten carbide-based cermet coatings. // Wear. 225, (1999), pp. 135-145. https://doi.org/10.1016/S0043-1648(99)00007-1

[4] Li, Z.; Jiang, Y.; Zhou, R.; Lu, D.; Zhou, R. Dry three-body abrasive wear behavior of WC reinforced iron matrix surface composites produced by V-EPC infiltration casting process. // Wear. 262, (2007), pp. 649-654. https://doi.org/10.1016/j.wear.2006.07.009

[5] Rombouts, M.; Persoons, R.; Geerinckx, E.; Kemps, R.; Mertens, M.; Hendrix, W.; Chen, H. Development and characterization of nickel based tungsten carbide laser cladded coatings. // Physics Procedia. 5, (2010), pp. 333339. https://doi.org/10.1016/j.phpro.2010.08.154

[6] Mendez, P. F.; Barnes, N.; Bell, K.; Borle, S. D.; Gajapathi, S. S.; Guest, S. D.; Izadi, H.; Gol, A. K.; Wood, G. Welding processes for wear resistant overlays. // Journal of Manufacturing Processes. 16 (2014), pp. 4-25. https://doi.org/10.1016/j.jmapro.2013.06.011

[7] Krejčí, L.; Hlavatý, I.; Ševčíková, X.; Transition zones study of the heterogeneous welded joints. // Metal. (2013), pp. 785-789.

[8] Mohyla, P.; Kuboň, Z.; Čep, R.; Samardžič, I. Evaluation of creep properties of steel P92 and its welded joint. // Metalurgy. 53, 2(2014), pp. 175-178.

[9] Just, C. H.; Badish, E.; Wosik, J. Influence of welding current on carbide/matrix properties in MMCs. // Journal of Materials Processing Technology. 210, (2010), pp. 408-414 https://doi.org/10.1016/j.jmatprotec.2009.10.001

[10] Badish, E.; Kirchgaßner, M. Influence of welding parameters on microstructure and wear behavior of a typical NiCrBSi hard facing alloy reinforced with tungsten carbide. // Surface and Coatings Technology. 202, (2008), pp. 6016-6022. https://doi.org/10.1016/j.surfcoat.2008.06.185

[11] Kamdi, Z.; Shipway, P. H.; Voisey, K. T.; Sturgeon, A. J.; Abrasive wear behaviour of conventional and large-particle tungsten carbide-based cermet coatings as a function of abrasive size and type. // Wear. 271, (2011), pp. 1264-1272. https://doi.org/10.1016/j.wear.2010.12.060

[12] Van Acker, K.; Vanhoyweghen, D.; Persoons, R.; Vangrunderbeek, J. Influence of tungsten carbide particle size and distribution on the wear resistance of laser clad WC/Ni coatings. // Wear. 258, (2005), pp. 194-202. https://doi.org/10.1016/j.wear.2004.09.041

[13] Sliding abrasion test (ASTM G65). $\mathrm{http} / / / \mathrm{www} . c r e u s a b r o . c o m /$ concept/laboratory_wear_tests/s liding.aspx (Accessed 2015-1-29)

[14] Krolczyk G.M., Nieslony P., Krolczyk J.B., Samardzic I., Legutko S., Hloch S., Barrans S., Maruda R.W. Influence of argon pollution on the weld Surface Morphology. // Measurement, 70, (2015) pp. 203-213. https://doi.org/10.1016/j.measurement.2015.04.001.

[15] Kumar, R.; Chattopadhyaya, S.; Hloch, S.; Krolczyk, G.; Legutko, S. Wear Characteristics and Defects Analysis of Friction Stir Welded Joint of Aluminium Alloy 6061-T6. // Eksploatacja i Niezawodnosc - Maintenance and Reliability. 18, 1(2016), pp. 128-135.

[16] Krolczyk, J. B.; Gapinski, B.; Krolczyk, G. M.; Samardzic, I.; Maruda, R. W.; Soucek, K.; Javadi, Y.; Legutko, S.; Nieslony, P.; Stas, L. Topographic Inspection as a Method of Weld Joint Diagnostic. // Tehnicki vjesnik-Technical Gazette. 23, 1(2016), pp. 301-306. https://doi.org/10.17559/TV-20141230182054 


\section{Authors' addresses}

Ivo Hlavatý, Assoc. Prof., PhD, Msc.

VŠB-Technical University of Ostrava

Faculty of Mechanical Engineering

Department of Mechanical Technology

17. listopadu 15, 708 33, Ostrava, Czech Republic

E-mail: ivo.hlavaty@vsb.cz

Jindřich Kozák, Msc.

VŠB-Technical University of Ostrava

Faculty of Mechanical Engineering

Department of Mechanical Technology

17. listopadu 15, 708 33, Ostrava, Czech Republic

E-mail: jindrich.kozak@vsb.cz

\section{Lucie Krejčí, PhD, Msc}

VŠB-Technical University of Ostrava

Faculty of Mechanical Engineering

Department of Mechanical Technology

17. listopadu 15, 708 33, Ostrava, Czech Republic

E-mail: lucie.krejci@vsb.cz

Ivan Samardžić, Prof. dr. sc.

University of Osijek

Faculty of Mechanical Engineering

Trg Ivane Brlić-Mažuranić 2, HR-35000 Slavonski Brod, Croatia

E-mail: ivan.samardzic@sfsb.hr

Jari Tuominen, prof. Dr.

Tampere University of Technology

Department of Materials Science

P.O. Box 589, FI-33101 Tampere, Finland

E-mail: jari.tuominen@tut.fi 